\title{
The Ecosystem Based Fishery Management in the Arctic - Imperative of our Time (WWF Russia Experience)
}

\author{
Konstantin Zgurovsky* \\ Senior Advisor of the WWF Russia Sustainable Fishery Program, Russia
}

Submission: September 02, 2017; Published: November 10, 2017

*Corresponding author: Konstantin Zgurovsky, PhD, Senior Advisor of the WWF Russia Sustainable Fishery Program, Russia, Tel: 7-495-727-0939; Email: KZgurovsky@wwf.ru

\section{Opinion}

The Arctic and adjusted waters is a home of several biggest stocks of the white fish (AK Pollock, Atlantic and Pacific cod, haddock), herring and Pacific salmon. Due to climate change, the Arctic ice coverage drastically decreasing, more open space for fishing operations appears and new fishing grounds could be discovered. A long term sustainable usage of traditional fishing stocks and new Arctic fishing areas require complex comprehensive planning.

Fisheries in the Arctic are spread out, separated by ice and landmasses, and large portions of fisheries lie well within the jurisdiction of individual countries. Bilateral fishing agreements already exist between the Arctic nations and one of options to introduce the Ecosystem Based Fishery Management (EBFM) in practice - to rely on them.In addition to the bilateral treaties that already exist between the nations with Arctic territory (USA, Canada, Russia, Norway, and Denmark) -Arctic fisherieswould be subject to at least three main international instruments: the Law of the Sea, the UN StraddlingStocks Agreement, and the FAO Compliance Agreement. But countries may have little incentive to enter international agreements for fisheries within Exclusive Economic Zones (EEZ). One of the reasons EBFM is appealing as a fisheries management instrument because it could force countries to use new approaches to fisheries management, rather than relying on existing treaties.

20 percent of the protein in the world comes from the sea. And if we cannot maintain this wealth, all of us can feel the loss. Fisheries management should be considered in terms of the ecosystem because fish of one species alters the ocean food chain as a whole - and sometimes we do not have enough data to prepare the necessary recommendations. This approach is called ecosystem based fishery management - EBFM.

Comprehensive ecosystem approach to fisheries management requires that address interactions with predators and stock competitors, availability of food, the effects of weather and climate on fisheries; complex relationship between the target species and their habitats, and the impact of fishing on fish stocks and habitat.

Arctic and adjacent waters are home to several large stocks of white fish (Walleye Pollock, Atlantic and Pacific cod, haddock, and herring and Pacific salmon). Due to climate change the area of Arcticice is reduced, there is more open space for fishing. Longterm sustainable use of fisheries resources in the traditional fishing areas and new Arctic ones requires a comprehensive, ecosystem-based planning. EBFM should become a common practice in the world. It is designed to regulate fishing in the overall scheme of conservation, balancing their service with the competing interests of natural resources.

Management of fisheries - is part of the so-called system integrated (or integral - ocean integral management) management of resources of the sea, not just biological. WWF is working to implement EBFM in two large so-called eco-regions: the Barents Sea and the Bering Sea (the latter includes the Bering and Okhotsk Seas).

The best long-term solution to fisheries regulation is an ecosystem regime overseen by a central governing body.The most obvious candidate - the Arctic Council, an intergovernmental body to promote the goals of sustainable development and environmental protection.But while the Arctic treaty has not been signed yet, and the Arctic Council has rather limited influence, the WWF is working on national and bilateral levels on the EBFM introduction. The WWF Russia concentrated on two big so-named ecoregions: Barents and Bering Seas ecoregions (last one includes the Bering Sea and the Sea of Okhotsk).

Responsible fishermen recognize the need to improve the practice of monitoring and management of fisheries.We are in tight negotiations with fishery scientists and biggest fishermen 
associations and companies, including Union of Fishermen of the North (UFN), Norebo/Karat Group, Arkhangelsky Trawl Fleetand F.E.S.T. Group and Alaska Pollock Catchers Association (PCA) on Guidelines creation for Fisheries Improvement Plan (FIP) using the EFBM principles.

WWF insists onnecessary steps to develop and adopt a number of inter-related measures in this regard:

-promote more deep involvement of fishermen in the fisheries management, so named Right Based Management (RBM), adoption of governmental policies to place independent fishery observers' onboard trawling vessels, further development of the Russian national Strategy on IUU fighting, create a fund to finance innovative sustainable fishing gears and practices, transfer to improved vessel monitoring measures, develop and adopt methodology on IUU fishing assessing. Regarding marine spatial planning, the fishermen, our partners agreed to support distinguishing and avoidance ofvulnerable marine ecosystems and improvement of the fishing gears. We also believe that it is necessary to assess the capacity of the Russian fishing fleet versus available fish stocks to avoid fleet over-capacity. WWF studies on the Russian Barents Sea cod fishery showed that fleet over-capacity is a strong incentive for IUU fishing.

The EBFM and RBM are becoming common practices in the World. It is intended to regulate fisheries as part of an overall scheme of resources management and marine ecosystems' conservation, balancing their exploitation against competing natural resources exploitation interests. But without international collaboration it is very hard to do. The WWF Russia would be happy to work together with all interested parties on the EFBM and RBM introduction into everyday practices.

\section{Your next submission with Juniper Publishers will reach you the below assets}

- Quality Editorial service

- Swift Peer Review

- Reprints availability

- E-prints Service

- Manuscript Podcast for convenient understanding

- Global attainment for your research

- Manuscript accessibility in different formats

( Pdf, E-pub, Full Text, Audio)

- Unceasing customer service

Track the below URL for one-step submission https://juniperpublishers.com/online-submission.php 